\title{
Anti-inflammatory properties of the ruthenium polypyridyl complex, K314, on the in vitro activated macrophages
}

\author{
Furkan AYAZ $1 *$ (D) \\ 1 Department of Biotechnology, Faculty of Arts and Science, Mersin University, Mersin, 33110, Turkey \\ * Corresponding Author. E-mail: furkanayaz@mersin.edu.tr; Tel: +90-532-171-9722 (F.A).
}

Received: 06 September 2018 / Revised: 16 October 2018 / Accepted: 26 October 2018

\begin{abstract}
Ruthenium polypyridyl complex derivatives find applications in the solar cells. They are mostly used as photosensitizers in solar cells for energy production. In our study we examined their activities on the immune system cells. At cellular level metabolic activities are shaped by the electron transfer reactions and ruthenium polypyridyl complexes can very well interfere this process and alter the outcome. A change in the cell's metabolism would lead to a change in the cell's activity. Depending on the functional group types attached to the ruthenium complex there can be changes in their biological function. Therefore our group has been screening their different derivatives' effects on the immune system cells inflammatory activity. We primarily focus on macrophages that are crucial cells of the innate immunity. In order to measure the activity of the macrophage cell line we detected the changes in the pro-inflammatory TNFa, IL1 $\beta$ and IL6 cytokine levels by ELISA. Our in vitro results support that K314 can be used as an anti-inflammatory $\mathrm{dr} \mu \mathrm{g}$ candidate in autoimmune diseases or inflammatory disorders. Furthermore, K314 can also be used as a surface coating material on the patches to prevent the inflammation in the area; as well as organ and tissue transplants, especially bone tissue, to suppress the inflammation mediated rejection of the transplant.
\end{abstract}

KEYWORDS: TNFa; IL-6; IL-1 $\beta$; inflammation; macrophage; immunomodulation; anti-inflammatory molecules; innate immunity

\section{INTRODUCTION}

Photosensitizers of the solar cells are able to convert the photons into electrical energy by generating electrons that can get transferred between the chemicals of the solar cells. There have been studies showing the efficiency of the ruthenium based complexes as photosensitizers [1-3]. Due to their electron transfer capacities, we hypothesized that these molecules could also find applications in biotechnology. Cell metabolism is regulated by multiple electron transfer reactions[4]. Interfering into this process might result in desired outcome in terms of cellular activity. We focused on the function of immune system cells, macrophages and there have been a body of studies supporting the rationale that regulation of the cellular metabolism could enable us modulation of the immune system cells' activity[4]. Through this modulation, we could manipulate our immune response to fight more efficiently against the danger or to tame it in case of the inflammatory disorders and autoimmune diseases. K314 was the ruthenium polypyridyl based complex derivative that focused on in our study[1-3].

Bacterial, fungal or viral particles or their metabolic byproducts, intracellular molecules of our cells that get released due to tissue damage, self antigens in case of the autoimmune diseases, food molecules in case of the allergies and tumor associated macromolecules in case of the cancer can all activate our immune system cells [5-16]. The efficiency of this activation as well as the proper type of an immune response defines the success of our immunity against these dangers [5-16]. Cytokines or chemokines produced by our immune system cells and associated tissue resident cells determine the fate of the immune response both in terms of its efficiency as well as the appropriateness of the type of the response [5-16]. Macrophages are the major cell types that can produce different types of cytokines and can also engulf, process and present the danger associated antigens to other immune system cells, especially $\mathrm{T}$ cells [5-16]. Due to their unique bridging capacity in the immune system these cells are ideal targets to regulate the immune function under certain

How to cite this article: Ayaz F. Anti-inflammatory properties of the ruthenium polypyridyl complex, K314, on the in vitro activated macrophages. J Res Pharm. 2019; 23(2): 164-169. 
disease conditions [5-16]. Upon activation by a danger signal and sometimes by environmental signaling cues these cells initiate a pro-inflammatory immune response[5-16]. TNFa, IL1 $\beta$, IL6 and GMCSF are among the pro-inflammatory cytokines produced by the macrophages [5-16].

Immunostimulatory or immunomodulatory molecules and drug candidates bring an immense potential to our ability to cope with diseases ranging from cancer to autoimmune disorders to infectious diseases [1729]. Therefore, in this study we aimed to examine the immunostimulatory and immunomodulatory activities of the ruthenium complex K314 on one of the main cell types of the innate immunity. For this purpose, we utilized from mouse macrophage cell line and activated them by a danger mimic lipopolysachharide (LPS) in vitro in the presence of K314. In order to measure the changes in the macrophage function we measure TNFa, IL1 $\beta$ and IL6 pro-inflammatory cytokine levels by ELISA. For the first time in the literature we are presenting data supporting the anti-inflammatory role of solar cell photosensitizer K314 on the in vitro activated macrophages.

\section{RESULTS}

Firstly the cytotoxic effect of K314 was measured by Trypan Blue staining and according to our results in Figure 1, K314 did not change the percentages of the live cells compared to the control wells. This supports that K314 was biocompatible at used concentrations. Only LPS applied cells were our positive controls and in Figures 2-4 we detected substantial production levels for TNFa, IL1 $\beta$ and IL6 by the stimulated macrophages. In order to test immunostimulatory activity of K314, macrophages were treated with $1 \mu \mathrm{g} / \mathrm{ml}$ and $10 \mu \mathrm{g} / \mathrm{ml}$ of it in the absence of LPS. K314 did not have immunostimulatory activity based on the pro-inflammatory cytokine secretion levels (Figure 2-4). $1 \mu \mathrm{g} / \mathrm{ml}$ of $\mathrm{K} 314$ had a mild anti-inflammatory effect on the LPS activated macrophages based on the TNFa and IL1 $\beta$ production levels compared to the only LPS stimulated positive control wells; but this effect was more vigorous at $10 \mu \mathrm{g} / \mathrm{ml}$ concentration of K314 (Figure 2-3). K314 did not affect the production of IL6 cytokine by LPS stimulated macrophages compared to the positive controls (Figure 4). Overall, these results support an immunomodulatory potential of K314 on in vitro activated mammalian macrophages.

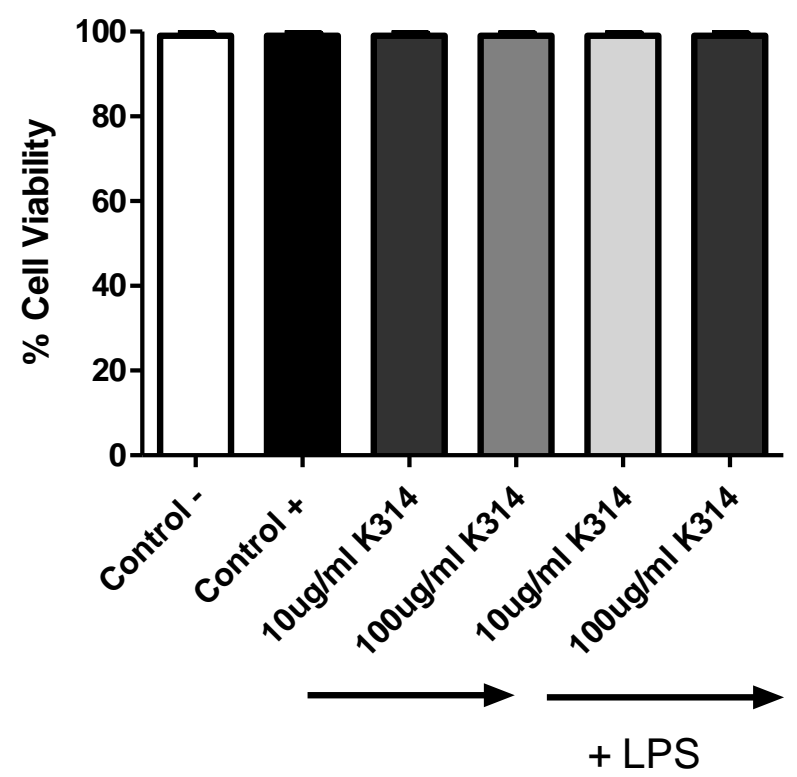

Figure 1. Percentage of viable cells were counted with Trypan blue staining after stimulating RAW macrophage cells for 24 hours with 10 and $100 \mu \mathrm{g} / \mathrm{ml}$ of K314. 1X106cells/ml cell concentration was used and distilled water was used for negative control, $1 \mu \mathrm{g} / \mathrm{ml}$ of LPS and distilled water was used for positive control and 10 and $100 \mu \mathrm{g} / \mathrm{ml}$ of the chemicals dissolved in distilled water with or without LPS were applied to the cells. Student $t$ test was applied for statistical analysis, ${ }^{*} \mathrm{p}<0.001,{ }^{* *} \mathrm{p}<0.0005,{ }^{, * *} \mathrm{p}<0.0001 \mathrm{~N}=9$. 


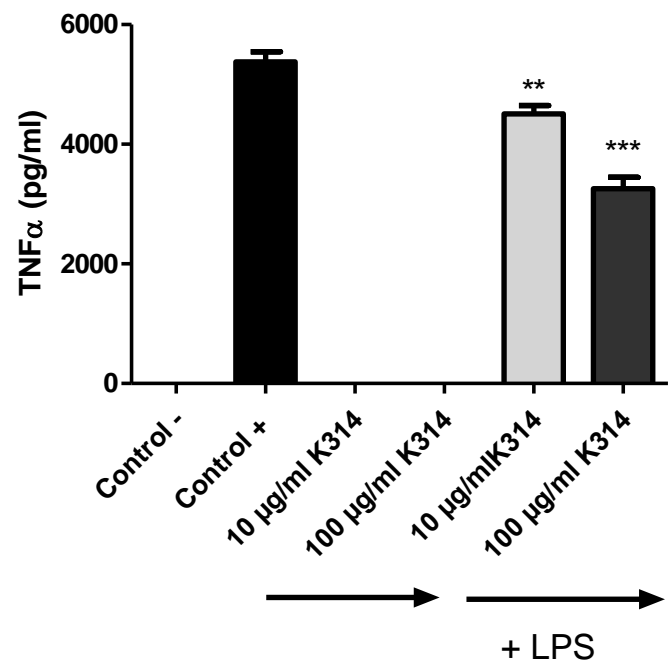

Figure 2. TNFa ELISA for the supernatants of RAW macrophage cells stimulated for 24 hours with 10 and $100 \mu \mathrm{g} / \mathrm{ml}$ of $\mathrm{K} 314$. 1X106cells/ml cell concentration was used and distilled water was used for negative control, $1 \mu \mathrm{g} / \mathrm{ml}$ of LPS and distilled water was used for positive control and 10 and $100 \mu \mathrm{g} / \mathrm{ml}$ of the chemicals dissolved in distilled water with or without LPS were applied to the cells. Student $\mathrm{t}$ test was applied for statistical analysis, $\mathrm{p}<0.001,{ }^{* *} \mathrm{p}<0.0005,{ }^{* * *} \mathrm{p}<0.0001 \mathrm{~N}=9$.

\section{DISCUSSION}

In this study the immunostimulatory and immunomodulatory activities of a ruthenium polypyridyl complex, K314, were tested on the in vitro activated macrophages. K314 was selected due to its possible interference to the electron transport processes in the biological cells since it can efficiently function as a photosensitizer in the solar cells by regulating the electron mobility after detection of the photons [1-3]. We aimed that by altering the electron transportation efficiency within the cells we could change its function and modulate the immune system cells. Studies support the role of metabolism which is determined by this electron flow within the cells on the type and strength of the immune reactions [4].

Macrophages are the main producers of the pro-inflammatory cytokines after detecting the danger associated molecules within the tissue[5-16]. Among the pro-inflammatory cytokines produced by the macrophages we focused on TNFa, IL1 $\beta$ and IL6. By utilizing from ELISA method their production levels were detected in the presence of K314. LPS from E.coli is a widely used positive control stimulus for the macrophages and we used $1 \mu \mathrm{g} / \mathrm{ml}$ of LPS on the macrophages to have positive reference points for the production of TNFa, IL1 $\beta$ and IL6 [5-16]. K314 did not induce and activity on macrophages by itself which could be advantageous during its in vivo applications since it would not lead to an unnecessary activity of the immune system cells (Figure 2-4). We did not detect any changes in the cell viability when K314 was applied to the cells and this supports its biocompatibility (Figure 1). K314 had immunomodulatory potential on TNFa and IL1 $\beta$ production levels by the LPS activated macrophages and this immunomodulatory effect was stronger at higher concentration (Figure 2 and 3). According to our unpublished data, ruthenium polypyridyl based derivatives differentially regulate the cytokine production and do not alter IL6 production by the in vitro activated macrophages. In line with those results, K314 did not change the IL6 production of LPS stimulated macrophages.

By generating a wide variety of immunomodulatory and immunostimulatory molecules we can manipulate the immune system cells and use them in medicine to eliminate the symptoms and cure the disease conditions [17-29]. These molecules can be used as adjuvant if they boost the immune responses [17-29]. If they exert an anti-inflammatory profile they can be used to suppress the excessive inflammatory reactions in the autoimmune diseases as well as in allergic reactions and inflammatory disorders. Moreover, these chemical agents can be used to coat the surfaces of the transplants and enable suppression of the graft rejections due to the inflammatory responses generated during the transplantation. K314 was able to significantly suppress the TNFa and IL1 $\beta$ production by the macrophages while not affecting the IL6 production. This pattern could be useful to generate the wound healing while suppressing the excessive inflammatory reactions since IL6 is involved in wound healing processes. K314 does not completely knockout 
TNFa and IL1 $\beta$ production and this is another advantage of the molecule since we would not want to immunocompromise the patients during the treatment to prevent possible infections.

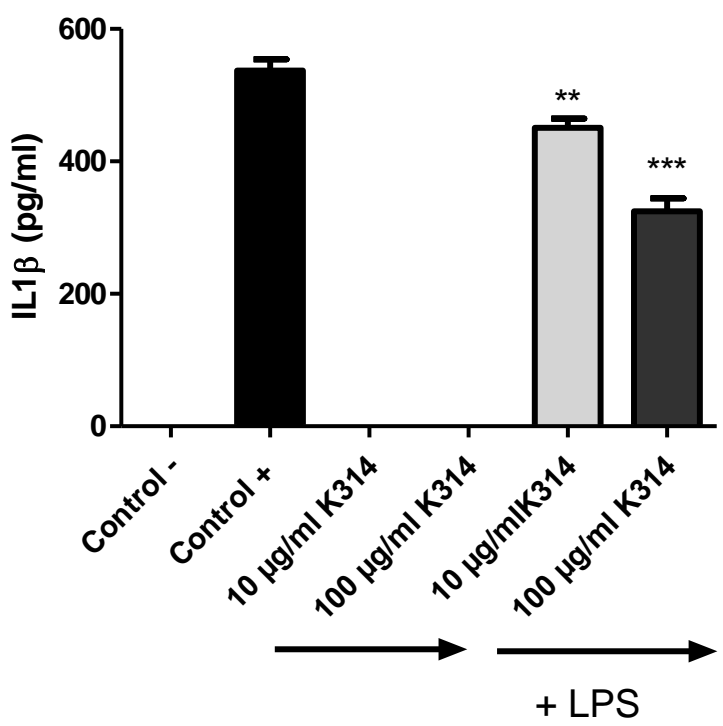

Figure 3. IL1b ELISA for the supernatants of RAW macrophage cells stimulated for 24 hours with 10 and $100 \mu \mathrm{g} / \mathrm{ml}$ of K314. 1X106cells / ml cell concentration was used and distilled water was used for negative control, $1 \mu \mathrm{g} / \mathrm{ml}$ of LPS and distilled water was used for positive control and 10 and $100 \mu \mathrm{g} / \mathrm{ml}$ of the chemicals dissolved in distilled water with or without LPS were applied to the cells. $5 \mathrm{mM}$ freshly prepared ATP solution was applied to the cells 2 hours before the harvest to stimulate this cytokine's secretion. Student $t$ test was applied for statistical analysis, $p<0.001,{ }^{* *} p<0.0005,{ }^{* * *} \mathrm{p}<0.0001 \mathrm{~N}=9$.

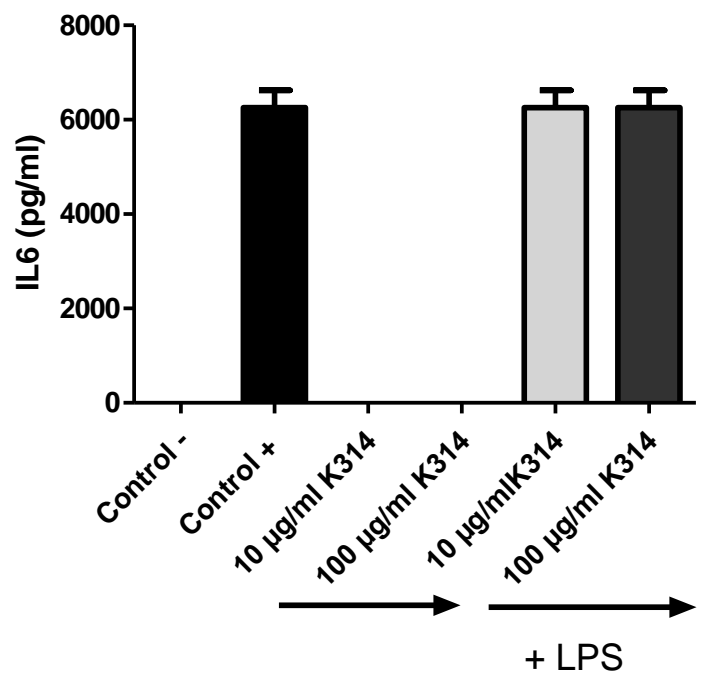

Figure 4. IL6 ELISA for the supernatants of RAW macrophage cells stimulated for 24 hours with 10 and 100 $\mu \mathrm{g} / \mathrm{ml}$ of K314. 1X106cells $/ \mathrm{ml}$ cell concentration was used and distilled water was used for negative control, $1 \mu \mathrm{g} / \mathrm{ml}$ of LPS and distilled water was used for positive control and 10 and $100 \mu \mathrm{g} / \mathrm{ml}$ of the chemicals dissolved in distilled water with or without LPS were applied to the cells. Student $\mathrm{t}$ test was applied for statistical analysis, $\mathrm{p}<0.001,{ }^{* *} \mathrm{p}<0.0005,{ }^{* * *} \mathrm{p}<0.0001 \mathrm{~N}=9$.

\section{CONCLUSION}

Overall, K314 is an immunologically inert, biocompatible and water soluble anti-inflammatory molecule that can be used against inflammation in versatile disease conditions. In our future studies we will be screening more ruthenium based complexes and will delineate their molecular mechanism of action within 
the macrophages. Our overarching aim is determining K314's in vivo efficacy as well as activity on other immune system cells, $\mathrm{T}$ cells and Dendritic cells.

\section{MATERIALS AND METHODS}

\subsection{In vitro cell activation studies}

Cell culture: RAW 264.7 cells were bought from ATCC. Complete cell media consisted of Roswell Park Memorial Institute media (RPMI 1640) media with $10 \%$ fetal bovine serum, $1 \%$ antibiotics $(100 \mu \mathrm{g} / \mathrm{ml}$ penicillin and $100 \mathrm{\mu g} / \mathrm{ml}$ streptomycin) and sodium pyruvate. Incubations were conducted in $37{ }^{\circ} \mathrm{C} 5 \% \mathrm{CO}_{2}$ humidified incubator.

Production of K314: The protocols in references 1-3 were followed for the production of K314. Due to its water soluble property it was dissolved in distilled water before applying it to the cells.

K314 and lipopolysachharide (LPS) stimulation of the mammalian macrophages: $10^{6}$ cells/well concentration was used in $1 \mathrm{ml}$ fresh complete RPMI in 24-well plates. Before the experiments cells were rested overnight in the incubators. $1 \mu \mathrm{g} / \mathrm{ml}$ and $10 \mu \mathrm{g} / \mathrm{ml} \mathrm{K} 314$ was applied to the macrophages in the absence and presence of the danger stimulus LPS. $1 \mu \mathrm{l}$ of LPS $(1 \mathrm{mg} / \mathrm{mL}$, Enzo Life Sciences, Salmonella minnesota R595) was used in $1 \mathrm{~mL}$ media. The same volume of distilled water was put in the negative control and LPS only control wells. Macrophages were incubated with K314, and LPS for 24 hours. After 24 hours the supernatants of each well were collected and put at $-80^{\circ} \mathrm{C}$. All experimental conditions were done in triplicates and these triplicates were repeated at least in four different experimental set ups. In order to measure the IL1 $\beta$ production by RAW 264.7 cells, freshly prepared 5mM ATP (Fisher Scientific) was added into the each well 2 hours before the harvest. The same experimental set up as stated above was used.

TNFa, IL6 and IL1 $\beta$ ELISAs: Enzyme-linked immunosorbent assay (ELISA) kits were purchased from BD biosciences for TNFa, IL6 and IL1 $\beta$ cytokines. Manufacturers instructions were followed for the ELISAs. Cell viability: After the incubation the media was transferred into the eppendorf tubes and adherent cells were resuspended in PBS for dead versus live cell counting with Trypan Blue under the microscope.

\subsection{Statistical analysis}

GraphPad Prism Software version 5 was utilized for ploting the graphs and statistical analysis. Nine independent biological results were plotted for each data set.Student $t$ test was applied for statistical analysis, ${ }^{*} \mathrm{p}<0.001,{ }^{* *} \mathrm{p}<0.0005,{ }^{* * *} \mathrm{p}<0.0001 \mathrm{~N}=9$.

Acknowledgement: I greatly appreciate the material supports of Prof. Dr. Kasım Ocakoğlu from Tarsus University and Prof.Dr. Juan Anguita from CICBiogune.

Author contributions: Concept - F.A.; Supervision - F.A.; Materials F.A.; Data Collection and/or Processing - F.A.; Analysis and/or Interpretation - F.A.; Literature Search - F.A.; Writing - F.A.; Critical Reviews - F.A.

Conflict of interest statement: The author declared no conflict of interest in the manuscript.

\section{REFERENCES}

[1] Ocakoglu K, Okur S, Aydin H, Guloglu P, Emen FM. The effect of annealing temperature on the optical properties of a ruthenium complex thin film. Thin Solid Films. 2016; 612(2): 225-230. [CrossRef]

[2] Ocakoglu K, Zafer C, Cetinkaya B, Icli S. Synthesis, characterization, electrochemical and spectroscopic studies of two new heteroleptic Ru(II) polypyridyl complexes. Dyes Pigm. 2007; 75(1): 385-394. [CrossRef]

[3] Ocakoglu K, Harputlu E, Guloglu P, Erten-Ela S. The photovoltaic performance of new ruthenium complexes in DSSCs based on nanorod ZnO electrode. Synthetic Metals. 2012; 23(1); 2125-2133. [CrossRef]

[4] Buck MD, Sowell RT, Kaech SM, Pearce EL. Metabolic instruction of immunity. Cell. 2017; 1(1): 570-586. [CrossRef]

[5] Arango Duque G, Descoteaux A. Macrophage cytokines: Involvement in immunity and infectious diseases. Front Immunol. 2014; 5(1): 491. [CrossRef]

[6] Murray RZ, Stow JL. Cytokine secretion in macrophages: SNAREs, rabs, and membrane trafficking. Front Immunol. 2014; 5: 538. [CrossRef] 
[7] Kawagishi C, Kurosaka K, Watanabe N, Kobayashi Y. Cytokine production by macrophages in association with phagocytosis of etoposide-treated P388 cells in vitro and in vivo. Biochim Biophys Acta, (BBA) - Mol Cell Res. 2001; 1541 (3): 221-230.[CrossRef]

[8] Cavaillon JM. Cytokines and macrophages. Biomed Pharmacother. 1994; 48 (10): 445-453. [CrossRef]

[9] Scull CM, Hays WD, Fischer TH. Macrophage proinflammatory cytokine secretion is enhanced following interaction with autologous platelets. J Inflam. 2010;7:53.[CrossRef]

[10] Berghaus LJ, Moore JN, Hurley DJ, Vandenplas ML, Fortes BP, Wolfert MA and Boons GJ. Innate immune responses of primary murine macrophage-lineage cells and RAW 264.7 cells to ligands of Toll-like receptors 2, 3, and 4. Comp. Immunol Microbiol Infect Dis. 2010; 33(5), 443-454.[CrossRef]

[11] Schmitz F, Mages J, Heit A, Lang R, Wagner H. Transcriptional activation induced in macrophages by Toll-like receptor (TLR) ligands: from expression profiling to a model of TLR signaling. Eur J Immunol. 2004; 34(10): 28632873.[CrossRef]

[12] Soromou LW, Zhang Z, Li R, Chen N, Guo W, Huo M, Guan S, Lu J, Deng X. Regulation of inflammatory cytokines in lipopolysaccharide-stimulated RAW 264.7 murine macrophage by 7-O-methyl-naringenin. Molecules. 2012; 17(3): 3574-3585. [CrossRef]

[13] Gasparini C, Foxwell BM, Feldmann M. RelB/p50 regulates TNF production in LPS-stimulated dendritic cells and macrophages. Cytokine. 2013; 61(3): 736-740.[CrossRef]

[14] Parameswaran N, Patial S. Tumor Necrosis Factor-a Signaling in Macrophages. Crit Rev Eukaryot Gene Expr. 2010; 20(2): 87-103.

[15] Lopez-Castejon G, Bro $\mu$ gh D. Understanding the mechanism of IL-1 $\beta$ secretion. Cytokine Growth Factor Rev. 2011; 22(4): 189-195. [CrossRef]

[16] Manderson AP, Kay JG, Hammond LA, Brown DL, Stow JL. Subcompartments of the macrophage recycling endosome direct the differential secretion of IL-6 and TNFa. J Cell Biol. 2007; 178 (1): 57.[CrossRef]

[17] Broide DH. Immunomodulation of allergic disease. Annu Rev Med. 2009; 60: 279-291.[CrossRef]

[18] Iwalewa EO, McGaw LJ, Naidoo V and Eloff JN. Inflammation: the foundation of diseases and disorders. A review of phytomedicines of South African origin used to treat pain and inflammatory condition. Afr J Biotechnol. 2007; 6 (25): 2868-2885.

[19] Hancock REW, Nijnik A and Philpott DJ. Modulating immunity as a therapy for bacterial infections. Nat Rev Microbiol. 2012; 10: 243-254.[CrossRef]

[20] Kaufmann T and Simon HU. Targeting disease by immunomodulation. Cell Death Differ. 2015; 22: 185-186.

[21] Julier Z, Park AJ, Briquez PS, Martino MM. Promoting tissue regeneration by modulating the immune system. Acta Biomaterialia. 2017; 1-42.[CrossRef]

[22] Khalil DN, Smith EL, Brentjens RJ, Wolchok JD. The future of cancer treatment: immunomodulation, CARs and combination immunotherapy. Nat Rev Clin Oncol. 2016; 13(5): 273-290.[CrossRef]

[23] Tan TT, Coussens LM. Humoral immunity, inflammation and cancer. Curr Opin Immunol. 2007; 19 (2): $209-216$. [CrossRef]

[24] Daniel CS and Ira M. oncology meets immunity. Immunity. 2013; 39 (1): 1-10. [CrossRef]

[25] Guevara-Patiño José A, Turk MJ, Wolchok JD, Houghton AN. Immunity to cancer through immune recognition of altered self: Studies with melanoma. Adv Cancer Res. 2003; 90: 157-177. [CrossRef]

[26] Valdés-Ramos R and Benítez-Arciniega A. Nutrition and immunity in cancer. Br J Nutr. 2007; 98(S1): S127-S132. [CrossRef]

[27] Grivennikov SI, Greten FR, Karin M. Immunity, inflammation, and cancer. Cell. 2010; 140(6): 883-899. [CrossRef]

[28] Rakoff-Nahoum S. Why cancer and inflammation?. Yale J Biol Med. 2006; 79 (3-4): 123-130.

[29] Coussens LM and Werb Z. Inflammation and cancer. Nature. 2002; 420 (6917): 860-867.[CrossRef] 